\title{
Modulation of Erythrocyte Membrane Mechanical Stability by 2,3-Diphosphoglycerate in the Neonatal Poikilocytosis/Elliptocytosis Syndrome
}

\author{
William C. Mentzer, Jr., " Terri A. larocci, ${ }^{*}$ Narla Mohandas," Peter A. Lane, ${ }^{*}$ Byron Smith, ${ }^{*}$ Jack Lazerson, ${ }^{*}$ and Taru Hays \\ *Departments of Pediatrics and Laboratory Medicine, University of California, San Francisco, California 94102; \\ †The Department of Pediatrics, University of California, Davis, California 95616; ' Denver Children's Hospital \\ and the Department of Pediatrics, University of Colorado School of Medicine, Denver, Colorado 80220
}

\begin{abstract}
To explain the transient anemia and poikilocytosis seen during infancy in hereditary elliptocytosis (HE), we resealed erythrocyte (RBC) ghosts from affected children or their elliptocytic parents with 2,3-diphosphoglycerate (DPG) (0-8 mM), a compound that dissociates membrane skeletons, then measured ghost mechanical stability in the ektacytometer. Without added 2,3-DPG, ghost mechanical stability was subnormal in infantile poikilocytosis (IP) and HE but was even more abnormal in hereditary pyropoikilocytosis (HPP). Addition of 2,3-DPG (2.55 mM) to IP or HE ghosts, decreased their stability to that of HPP ghosts (without 2,3-DPG). Nonphysiological 2,3-DPG levels (6-8 mM) were required to elicit a similar effect in normal ghosts. The data suggest that free 2,3-DPG, present in neonatal RBC as a consequence of diminished binding to $\mathrm{HbF}$, may render $\mathrm{HE}$ susceptible to in vivo fragmentation. The developmental switch from fetal to adult hemoglobin, by diminishing available free 2,3-DPG, may explain the abatement of poikilocytosis and hemolytic anemia that accompanies maturation.
\end{abstract}

\section{Introduction}

Transient hemolytic anemia and bizarre erythrocyte morphology, resembling that seen in hereditary pyropoikilocytosis, may occur in young infants from kindreds in which one parent has elliptocytosis (1-5). Affected infants, who have usually been Black, often require transfusion in early infancy for anemia or hyperbilirubinemia. At $\sim 6$ mo of age, hemolytic anemia disappears or diminishes in severity and, thereafter, erythrocyte morphology becomes more purely elliptocytic, like that of the affected parent.

The cause of these transient hematologic abnormalities is unknown. One proposed explanation is that the skeletal abnormality responsible for elliptocytosis is itself different in fetal red cells than in adult cells. Although there are definite differences that distinguish the membrane of the fetal red cell from that of adult erythrocytes (6), most available evidence indicates that the membrane skeleton and its component proteins are identical in

Address reprint requests to Dr. Mentzer, Room 2108, Building 20, San Francisco General Hospital, 1001 Potrero Avenue, San Francisco, CA 94110.

Presented in part to the American Society of Hematology, Miami, FL, December 1984.

Received for publication 4 March 1986 and in revised form 10 November 1986.

J. Clin. Invest.

(c) The American Society for Clinical Investigation, Inc. 0021-9738/87/03/0943/07 \$1.00

Volume 79, March 1987, 943-949 fetal and adult red cells (7-9). We therefore considered it more likely that developmental changes in nonskeletal red cell components capable of interacting with the underlying skeletal protein abnormality were responsible for transient neonatal poikilocytosis and hemolysis. In this report, we provide evidence that 2,3-diphosphoglycerate (DPG) ${ }^{1}$ can dissociate the flawed membrane skeleton of elliptocytic ghosts, causing such preparations to reach the extreme levels of mechanical fragility characteristic of hereditary pyropoikilocyte ghosts.

We propose that the uniquely high levels of free 2,3-DPG in fetal red cells, a consequence of the extremely limited ability of hemoglobin $\mathrm{F}$ to bind 2,3-DPG, render cells with an inherited membrane skeletal abnormality particularly susceptible to in vivo fragmentation and premature destruction.

\section{Methods}

Glycerate-2,3-diphosphate (pentacyclohexylammonium salt) was purchased from Boehringer Mannheim, Indianapolis, IN; electrophoresis reagents from Bio-Rad Laboratories, Richmond, CA; Seakem ME agarose from FMC Corporation, Rockland, ME; DFP from Sigma Chemical Co., St. Louis, MO; and Trypsin- $N$-tosyl-L-phenylalanine chloromethyl ketone (TPCK) from Worthington/Cooper Biomedical, Inc., Malvern, PA.

The study protocol was approved by the Committee on Human Research of the University of California, San Francisco.

Routine hematology. Routine blood counts were measured by electronic particle counter. The percentage of hemoglobin $F$ was determined by alkali denaturation or by densitometric scanning of cellulose acetate hemoglobin electrophoresis strips. The percentage of elliptocytes was determined by counting 500 cells on well separated areas of a peripheral blood smear.

Red cell thermal fragility. Morphologic changes such as membrane distortions or budding were studied by Nomarski interference phase microscopy after heating red cells suspended in BSKG buffer $(132 \mathrm{mM}$ $\mathrm{NaCl}, 5 \mathrm{mM} \mathrm{KCl}, 10 \mathrm{mM} \mathrm{NaHPO}, 11 \mathrm{mM}$ glucose, 290 mosM, pH 7.4) to various temperatures between $37^{\circ}$ and $50^{\circ} \mathrm{C}$ for $10 \mathrm{~min}(10)$. Fragmentation of heated erythrocytes was estimated by measuring the accumulation of small particles using a Coulter Counter (model ZBI, Coulter Electronics, Hialeah, FL) equipped with a channelizer II (10).

Deformability measurements. The deformability of intact red cells was measured in the ektacytometer, a couette viscometer, which applies a well-defined laminar shear stress to the cell, while simultaneously monitoring the extent of cell deformation by laser defractometry (11). To obtain information about initial cell surface area, surface area to volume ratio, and cell water content, the deformability of red cells was contin-

1. Abbreviations used in this paper: DFP, diisopropyl fluorophosphate; DI, deformability index; DPG, diphosphoglycerate; HE, hereditary elliptocytosis; HPP, hereditary pyropoikilocytosis; IP, infantile poikilocytosis; MCHC, mean corpuscular hemoglobin concentration; MCV, mean corpuscular volume; PAGE, polyacrylamide gel electrophoresis; PMSF, phenylmethylsulfonyl fluoride; TPCK, $N$-tosyl-L-phenylalanine chloromethyl ketone; $\mathrm{T}_{60}$, index of red cell or ghost mechanical stability. 
uously recorded as the suspending medium osmolarity was linearly increased from 50 to $500 \mathrm{mosM} / \mathrm{kg}$ (11).

Membrane stability assay. We measured membrane resistance to shear induced fragmentation by subjecting resealed ghosts to a constant shear stress of $\mathbf{5 7 5}$ dynes per square centimeter in the ektacytometer (12). Toward the end of 1984 , the original analogue processing ektacytometer was replaced by a second generation digital processing machine. Ghost mechanical stability assays were run at a higher shear stress $(650$ or $785 \mathrm{dyne} / \mathrm{cm}^{2}$ ) on this instrument. The major difference between the two instruments was the geometric location of the areas of the diffraction pattern selected for scattered light intensity measurements to generate the deformability index (DI). In the earlier system, the DI values generated were higher than in the later system. Because of these design changes, the relative DI changes during membrane stability measurements were different in the two systems. Ghosts were suspended in a dextran solution of 97 centipoise (cp) viscosity and the ektacytometer chamber rotated at a speed of 110-150 rpm to generate the desired shear stress. A decrease in the DI generated by the ektacytometer has been shown to reflect fragmentation of the intact membranes into small, undeformable spherical particles. As an index of the rate of this fragmentation process we selected the time required for the DI to fall to $60 \%$ of its highest value (T60). The $60 \%$ level was chosen because the rate of fall in DI that accompanied fragmentation exhibited greater variability at lower levels. To minimize small, day-to-day variation in the absolute value of the T60 due to fluctuations in such uncontrolled variables as room temperature, we always made comparison to simultaneously studied normal erythrocyte ghosts. The mechanical stability of intact red cells was also measured in the ektacytometer, using a higher shear stress $\left(1,300\right.$ dyne $\left./ \mathrm{cm}^{2}\right)(12)$.

Red cell membrane protein analyses. Red cell membrane ghosts were prepared essentially as described by Dodge et al. (13). Phenylmethylsulfonyl fluoride (PMSF) $0.2 \mathrm{mM}$, was added to all preparative solutions to minimize proteolysis. Red cell membrane proteins were analyzed by one-dimensional sodium dodecyl sulfate-polyacrylamide gel electrophoresis (SDS-PAGE) as described by Laemmli (14) using a 4.5\% acrylamide stacking gel and a 4-15\% nonlinear acrylamide gradient separating gel. A crude spectrin extract was obtained from fresh ghosts by dialysis for $20-24 \mathrm{~h}$ at $0-4^{\circ} \mathrm{C}$ in low ionic strength buffer containing $0.1 \mathrm{mM}$ sodium phosphate, $0.1 \mathrm{mM}$ ethylenediaminetetracetic acid, $0.1 \mathrm{mM} \beta$-mercaptoethanol and $0.2 \mathrm{mM}$ PMSF at pH 8 (10). The percentage of spectrin dimers (expressed as dimers/dimers plus tetramers) present in this extract was determined by nondenaturing polyacrylamide gel electrophoresis as described by Liu and Palek (15). The crude spectrin extracts were also subjected to limited tryptic digestion at $0-4^{\circ} \mathrm{C}$, essentially as described by Lawler and his co-workers (8). For these studies, the crude spectrin extracts were dialyzed for $16 \mathrm{~h}$ at $0^{\circ} \mathrm{C}$ against $200 \mathrm{vol}$ of $20 \mathrm{mM}$ Tris buffer, $\mathrm{pH} 8$, in order to remove PMSF. The protein concentration of the dialysed spectrin extract was determined using a Bio-Rad assay. Trypsin-TPCK was then added to the extract at ratios of $1: 100$ or $1: 200$ (wt/wt) and limited digestion allowed to proceed for $16-20 \mathrm{~h}$ at $0^{\circ} \mathrm{C}$ (16). The reaction was terminated by the addition of DFP to a final concentration of $1 \mathrm{mM}$ (16). Analysis of the spectrin fragments produced by digestion was carried out using a two-dimensional isoelectric focusing/ SDS-PAGE system (17).

\section{Preparation of resealed ghosts containing 2,3-DPG}

Fresh red cells were washed three times with Tris-saline buffer ( $5 \mathrm{mM}$ Tris, $140 \mathrm{mM} \mathrm{NaCl}, \mathrm{pH} 7.4$ ). $40 \mathrm{ml}$ of cold lysing buffer ( $5 \mathrm{mM}$ Tris, 7 $\mathrm{mM} \mathrm{NaCl}, \mathrm{pH}$ 7.4) was then added to $2 \mathrm{ml}$ of packed red cells. After gentle shaking, the suspension was centrifuged at $20,000 \mathrm{~g}$ for $5 \mathrm{~min}$ and the supernatant removed by aspiration. $2 \mathrm{ml}$ of the ghosts thus obtained were added to $20 \mathrm{ml}$ of cold resealing buffer ( $5 \mathrm{mM}$ Tris, $\mathrm{pH} 7.4$, plus $140 \mathrm{mM} \mathrm{NaCl})$ to which had been added various concentrations $(0-15$ $\mathrm{mM}$ ) of 2,3-DPG (cyclohexylammonium salt). After incubation at $37^{\circ} \mathrm{C}$ for $1 \mathrm{~h}$, the resealed ghosts were centrifuged at $20,000 \mathrm{~g}$ for $5 \mathrm{~min}$. Packed ghosts $(100 \mu \mathrm{l})$ were added to $35 \%$ dextran in 180 mosM phosphatebuffered saline (pH 7.4, final osmolarity, 290 mosM) and the ghost mechanical stability determined immediately in the ektacytometer as described earlier. Resealed ghosts could be held on ice for at least $2 \mathrm{~h}$ without any change in mechanical stability. All measurements were completed in $<1 \mathrm{~h}$ from completion of ghost preparation. For determination of 2,3-DGP levels, an aliquot of the packed ghosts were washed and suspended in saline at a hematocrit of $30-40 \%$, then extracted with perchloric acid. To prepare the extracts, an aliquot $(0.5 \mathrm{ml})$ of ghosts was added to $1 \mathrm{ml}$ of ice-cold $1 \%$ perchloric acid. The clear supernatant was neutralized with $5 \mathrm{M}$ potassium carbonate and stored for subsequent assay. 2,3-DPG was assayed spectrophotometrically by the method of Keitt (18).

\section{Case histories}

Family B. A.B., a Black infant born at term (birthweight, 3,525 g), required a two volume exchange transfusion at $48 \mathrm{~h}$ of life for hyperbilirubinemia. On the first day of life the hemoglobin was $13.4 \mathrm{~g} / \mathrm{dl}$, the mean corpuscular volume (MCV) $79 \mathrm{fl}$, and the reticulocyte count $5 \%$. Bizarre poikilocytes and elliptocytes were noted on the peripheral blood smear. At 19 wk of age the hemoglobin reached a nadir of $7.4 \mathrm{~g} / \mathrm{dl}$. The reticulocyte count was $12.8 \%$ and the spleen tip was palpable. At 51 wk of age, the hemoglobin was normal $(10.9 \mathrm{~g} / \mathrm{dl})$ but the reticulocyte count remained elevated (3.8\%), and the red cell indices were abnormal (MCV $65 \mathrm{fl}$, [mean corpuscular hemoglobin count] MCHC 36.2\%). At the age of $2 \mathrm{yr}$, following $2 \mathrm{~d}$ of fever $\left(104^{\circ}\right)$ and diarrhea, he required transfusions for an episode of severe anemia $(\mathrm{Hb}=5.9 \mathrm{~g} / \mathrm{dl})$. Red cell morphology continued to resemble that of hereditary pyropoikilocytosis and the spleen was now palpable $2 \mathrm{~cm}$ below the left costal margin. Peripheral blood counts and reticulocyte counts were normal in both parents. Red cell morphology was normal in the father but numerous elliptocytes were evident on the mother's peripheral blood smear.

Family D. Patient B.D., born at term (birthweight, 3,059 g), required hospitalization at day 4 of life for neonatal hyperbilirubinemia (peak bilirubin $16.7 \mathrm{mg} / \mathrm{dl}$ ). On admission, the hemoglobin was $11.7 \mathrm{~g} / \mathrm{dl}$, the reticulocyte count $2.8 \%$, and the red cell morphology resembled that of hereditary pyropoikilocytosis, with occasional pyknocytes also noted. By $5 \mathrm{wk}$ of age, the hemoglobin had fallen to $6.5 \mathrm{~g} / \mathrm{dl}$ and the patient was transfused. Thereafter, the hemoglobin remained above $9 \mathrm{~g} / \mathrm{dl}$ and the reticulocyte count and red cell indices were normal. Elliptocytes became increasingly prevalent on the blood smear, but even at 22 mo of age poikilocytic, microcytic fragments were still evident. Elliptocytes were abundant in the peripheral blood of the father, who was Black, but his peripheral blood counts were normal. Blood counts and red cell morphology were entirely normal in the mother, who was Caucasian. Patient P.D., the younger sibling of B.D., was treated with phototherapy for neonatal hyperbilirubinemia. A poikilocytic, hemolytic anemia (Hb $=13.3 \mathrm{~g} / \mathrm{dl}$ on day 5 of life), exactly like that noted in B.D., was present and gradually worsened, reaching a nadir $(\mathrm{Hb}=8 \mathrm{~g} / \mathrm{dl})$ at $6 \mathrm{wk}$ of age. Transfusions were not required and by $10 \mathrm{mo}$ of age the hemoglobin $(10.9 \mathrm{~g} / \mathrm{dl})$ and reticulocyte count $(0.2 \%)$ were normal.

Family $W$. S.W., a full-term Caucasian male, required phototherapy for neonatal hyperbilirubinemia. At birth, the hematocrit was $39 \%$ and the erythrocyte morphology resembled that of hereditary pyropoikilocytosis. By 6 wk of age, the hemoglobin had fallen to $7.9 \mathrm{~g} / \mathrm{dl}$ and the reticulocyte count was $13.7 \%$. By 25 wk of age the hemoglobin had risen to $12 \mathrm{~g} / \mathrm{dl}$ but reticulocytosis persisted (5\%). The red cell indices were normal and the erythrocyte morphology was now that of elliptocytosis rather than pyropoikilocytosis. The patient's mother, who was reportedly anemic during pregnancy but not at other times, had elliptocytosis but a normal reticulocyte count. The only sibling of S.W. required treatment for hyperbilirubinemia at birth and currently has elliptocytosis and reticulocytosis (1.8\%) but not anemia (hemoglobin $11.8 \mathrm{~g} / \mathrm{dl}$ ). The father was hematologically normal.

Family C. J.C., a full-term Caucasian female, (birthweight, 3,380 g), required phototherapy for neonatal hyperbilirubinemia. On the eighth day of life, the hemoglobin was $14.1 \mathrm{~g} / \mathrm{dl}$. Mild to moderate abnormalities of erythrocyte morphology were noted (anisocytosis, poikilocytosis, elliptocytosis). By 9 wk of age the hemoglobin had dropped to $7.5 \mathrm{~g} / \mathrm{dl}$. The reticulocyte count was $4.1 \%$ and the erythrocyte morphology resembled that of hereditary pyropoikilocytosis, with $12 \%$ pyknocytes also noted on the peripheral blood smear. By 30 wk of age, anemia was no longer 
present (hemoglobin $10.8 \mathrm{~g} / \mathrm{dl}$ ). The reticulocyte count and red cell indices were normal and the blood cell morphology was now consistent with hereditary elliptocytosis. The mother was not anemic but had elliptocytosis. The father and one sibling were hematologically normal.

\section{Hematologic studies}

The duration and extent of anemia in affected infants from the four families is shown in detail in Fig. 1. In general, the anemia reached a nadir at from 1 to $3 \mathrm{mo}$ of age and was no longer present at 6 mo. Tests for immune hemolysis were negative in each infant. The postnatal decline in the amount of hemoglobin F is also depicted in Fig. 1. In the four infants with poikilocytosis, the fall in hemoglobin $\mathrm{F}$ appeared to be slightly accelerated but still remained within the normal range. Serial red cell size distribution plots obtained in two infants are shown in Fig. 2. In patient B.D., a persistent population of extremely microcytic red cells was evident even at 22 mo of age. An equivalent population was not seen in the elliptocytic father. Red cell size distribution analyses were not performed on B.D. during the first few months of life, but were carried out on P.D., his younger brother, who had an identical poikilocytic anemia (Fig. 2). A sharp decline in the microcytic cell fraction was evident by 8 wk of age in P.D. In another infant (A.B.), unrelated to the first two, the fraction of cells that were extremely microcytic exceeded the fraction that were normal until 34 mo of age (data not shown). Even then, a large fraction of microcytic cells were present, the plot resembling that shown for P.D. at birth.

\section{Red cell fragmentation and deformability}

The temperature at which heated erythrocytes first exhibited morphologic changes (budding or fragmentation) is reported in Table I. Erythrocytes from the three Black infants (A.B., P.D., and B.D.) underwent thermal changes at temperatures up to 5 degrees below those characteristic of control erythrocytes. Between 1 and 2 yr of age the temperature required to induce morphologic changes rose toward normal in B.D. but showed no improvement in A.B. Erythrocytes from the elliptocytic parent of B.D. but not A.B. were susceptible to heat induced morphologic changes and fragmentation at temperatures 1-2 degrees lower than normal. The two Caucasian infants (S.W. and J.C.) and their family members were
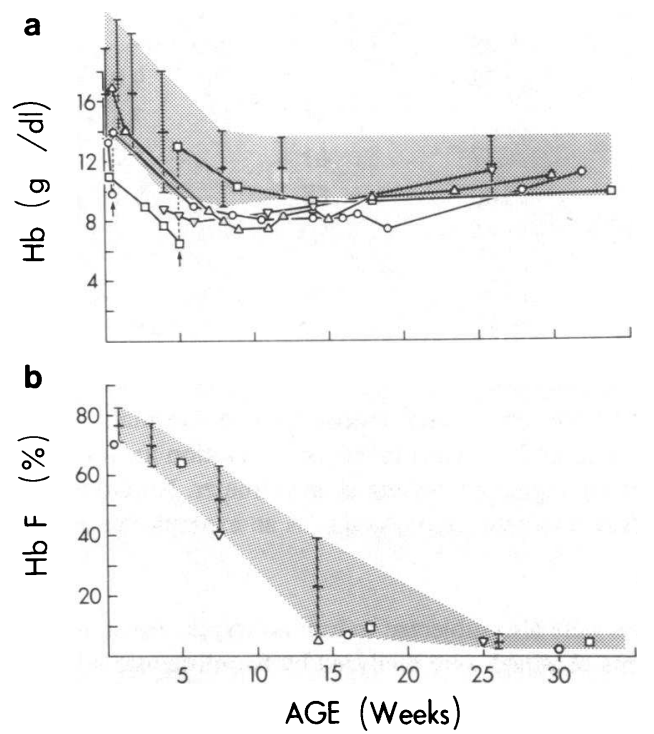

Figure 1. Hemoglobin (a) and hemoglobin F (b) levels during infancy in four infants with neonatal poikilocytosis and transient hemolytic anemia. $\nabla$ S.W., $\Delta$ J.C., $\circ$ A.B., $\square$ B.D., $\uparrow$ transfusion. The normal range (shown by the shaded area), mean, and standard deviation are also indicated $(26,31)$.

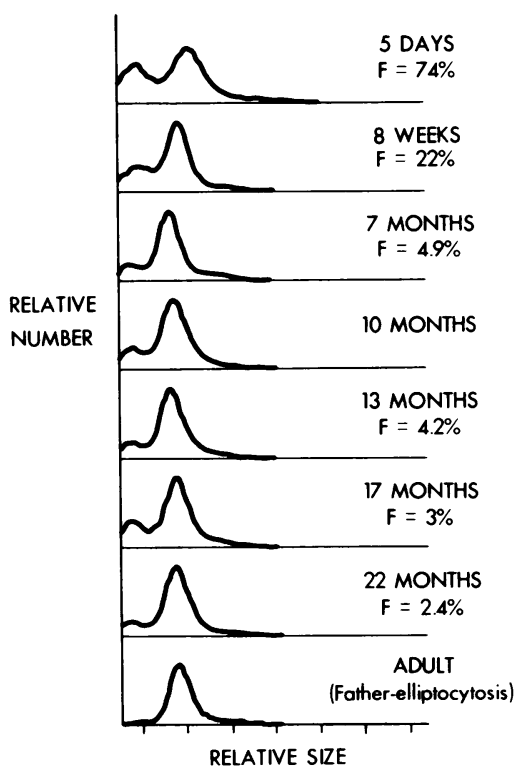

Figure 2. Red cell size distribution in neonatal poikilocytosis and transient hemolytic anemia (family D). (Top 2 panels) P.D. (Panels 3-7) B.D. (Bottom panel) father with elliptocytosis (K.D.). normal (J.C.) or exhibited a one degree decline (S.W.) in the temperature at which thermal changes occurred.

To evaluate whole cell deformability and investigate cell surface to volume relationships, erythrocytes were studied by the technique of osmotic gradient ektacytometry (Fig. 3). In this procedure the deformability of erythrocytes in a continuously changing osmotic environment is measured in the ektacytometer. Erythrocytes from three infants with transient poikilocytosis exhibited varying reductions in maximal deformability. In these three infants (J.C., S.W., and B.D.), the results were nearly identical to those obtained using erythrocytes from their elliptocytic parents (data not shown). In a fourth infant (A.B.), whose poikilocytosis persisted beyond age $2 \mathrm{yr}$, the reduction in deformability was more severe than that noted in his elliptocytic mother but not so severe as that typical of classic hereditary pyropoikilocytosis. In this family, but not in the others, the nonelliptocytic parent also exhibited a modest reduction in red cell deformability.

The mechanical stability of erythrocyte ghosts was measured by ektacytometry. In the infants with transient poikilocytosis and in their elliptocytic parents, ghost mechanical stability was reduced to roughly half normal (Table I). No consistent changes in ghost mechanical stability were associated with maturation in those infants in whom sequential studies were performed. In three families, the nonelliptocytic parent had no abnormalities of ghost mechanical stability but in the fourth (family B) a moderate reduction (to $74 \%$ of normal) was noted.

In family $D$, the mechanical stability of intact red cells was also evaluated by ektacytometry. Red cells from P.D. (age 5 d), B.D. (age 22 mo) and normal adult or neonatal controls were separated from subpopulations of equivalent buoyant density by Stractan density gradient centrifugation and a representative layer from the center of each gradient (red cell density $=1.093-1.098$ ) was subjected to ektacytometry. Red cell mechanical stability ( $T_{60}$ expressed as a percentage of the normal control), was subnormal ( $30 \%$ of normal) in B.D. and even more strikingly abnormal in P.D. ( $T_{60}=20 \%$ of normal). Subsequently, when P.D. was 10 mo old and no longer had poikilocytic hemolytic anemia, these studies were repeated. Red cell mechanical fragility, which had improved in both P.D. (51\%) and B.D. (42\%), now was identical to the value obtained for their elliptocytic father (45\%).

\section{Red cell membrane proteins}

One-dimensional SDS-PAGE of membrane proteins obtained from infants with transient poikilocytosis and their relatives was normal in three families. In the fourth (S.W.), an abnormal alpha spectrin mutant (apparent $235,000 \mathrm{~mol} \mathrm{wt}$ ) which migrated between the positions of normal 
Table I. Properties of Erythrocytes from Children with Infantile Poikilocytosis and Their Families

\begin{tabular}{|c|c|c|c|c|c|c|c|c|}
\hline & \multirow[b]{2}{*}{ Age } & \multicolumn{2}{|c|}{ RBC morphology } & \multicolumn{2}{|c|}{ RBC thermal changes } & \multicolumn{2}{|c|}{ Ghost mechanical stability } & \multirow{2}{*}{$\begin{array}{l}\text { Spectrin } \\
\text { dimers }\end{array}$} \\
\hline & & Appearance* & Elliptocytes & Morphology ${ }^{*}$ & Fragmentation & Analogue & Digital" & \\
\hline & $w k$ & & $\%$ & & & & & $\%$ \\
\hline \multicolumn{9}{|l|}{ Family B } \\
\hline \multirow[t]{6}{*}{ Infant (A.B.) } & 16 & HPP & 24 & $<46$ & 48 & 39 & & 35 \\
\hline & 32 & HPP & 26 & 44 & 49 & 42 & & - \\
\hline & 51 & HPP & 36 & 45 & 49 & 29 & & 28.5 \\
\hline & 82 & HPP & 39 & 45 & 50 & & 12 & 27.7 \\
\hline & $2 \mathrm{yr}$ & HPP & 39 & 45 & 49 & & - & - \\
\hline & $2^{10} / 12 \mathrm{yr}$ & HPP & 46 & - & - & & 16 & - \\
\hline Mother & & HE & 45 & 49 & 50 & 60 & 36 & 20.5 \\
\hline Father & & $\mathbf{N}$ & $<1$ & 49 & 50 & 74 & 39 & 16.1 \\
\hline \multicolumn{9}{|l|}{ Family D } \\
\hline \multirow[t]{3}{*}{ Infant (P.D.) } & 1 & IP & 29 & 46 & 49 & & $6+$ & - \\
\hline & 9 & IP & 29 & 47 & 49 & & $21+$ & - \\
\hline & 40 & $1 \mathrm{P} / \mathrm{HE}$ & 42 & - & - & & 23 & - \\
\hline \multirow[t]{8}{*}{ Infant (B.D.) } & 5 & IP & 31 & 47 & 49 & 45 & & 18.9 \\
\hline & 17 & IP/HE & 47 & 46 & 49 & 57 & & 13.5 \\
\hline & 32 & IP/HE & 51 & 46 & 49 & 41 & & - \\
\hline & 45 & IP/HE & 48 & 47 & 49 & 31 & 15 & - \\
\hline & 57 & IP/HE & 54 & 47 & 50 & & 19 & 14.7 \\
\hline & 73 & IP/HE & 56 & 48 & 50 & & 29 & - \\
\hline & 97 & HE & 63 & - & - & & $18+$ & - \\
\hline & $2^{8} / 12 \mathrm{yr}$ & HE & 43 & - & - & & 24 & \\
\hline Father & & HE & 62 & 48 & 49 & 41 & $30+, 16$ & 15.5 \\
\hline Mother & & $\mathbf{N}$ & $<1$ & 49 & 50 & 92 & 100 & 4.4 \\
\hline \multicolumn{9}{|l|}{ Family W } \\
\hline \multirow[t]{3}{*}{ Infant (S.W.) } & 7 & IP/HE & 56 & 49 & 50 & 36 & & - \\
\hline & 25 & HE & 71 & 48 & 50 & 46 & & 22.8 \\
\hline & 70 & HE & 64 & 48 & 49 & & 12 & 15.3 \\
\hline Mother & & HE & 83 & 49 & 50 & 67 & 32 & 15.1 \\
\hline Sibling & $5 \mathrm{yr}$ & HE & 70 & 49 & 50 & 46 & 12 & 15.7 \\
\hline Father & & $\mathbf{N}$ & 2 & 49 & 50 & 95 & 100 & 3.4 \\
\hline \multicolumn{9}{|l|}{ Family C } \\
\hline \multirow[t]{3}{*}{ Infant (J.C.) } & 8 & IP/HE & 9 & - & 50 & 59 & & - \\
\hline & 18 & HE & 26 & - & 50 & 78 & & 9.0 \\
\hline & $4^{10 / 12} \mathrm{yr}$ & HE & 22 & - & - & & 55 & 7.4 \\
\hline Mother & & HE & 35 & 49 & 50 & 77 & 61 & 5.2 \\
\hline Father & & $\mathbf{N}$ & 3 & 49 & 50 & 100 & 88 & 5.1 \\
\hline \multicolumn{9}{|l|}{ Normal } \\
\hline controls & & $\mathbf{N}$ & $<4$ & 49 & 50 & 100 & 100 & $5.72 \pm 2.05$ \\
\hline$n$ & & & 10 & 30 & 30 & 18 & 18 & 45 \\
\hline
\end{tabular}

* HPP, hereditary pyropoikilocytosis; HE, hereditary elliptocytosis; IP, infantile poikilocytosis; IP/HE, transitional morphology; N, normal.

${ }^{\ddagger}$ Lowest temperature $\left({ }^{\circ} \mathrm{C}\right)$ at which membrane budding observed in $>10 \%$ of $\mathrm{RBC}$. ${ }^{\S}$ Determined at 575 dyne $/ \mathrm{cm}^{2}$ in $1 \mathrm{st}$ generation analogue processing ektacytometer. "Determined at $653(+)$ or $784 \mathrm{dyne} / \mathrm{cm}^{2}$ in Technicon 2 nd generation digital processing ektacytometer. Note that simultaneous assay of mechanical stability on the same sample yielded different results in the two ektacytometer systems (as an example see results for family B parents).

alpha and beta spectrin, was identified. Details of this unique mutant are presented elsewhere (19). The percentage of spectrin dimers present in low ionic strength extracts of membrane ghosts, prepared at $0^{\circ} \mathrm{C}$, was considerably greater than normal in three infants and in their elliptocytic parents (Table I). No consistent change in the amount of spectrin dimers was detected during the evolution from poikilocytosis to elliptocytosis in these infants. In the fourth family, the percentage of spectrin dimers was normal to slightly increased in the affected infant (J.C.) and was normal in both parents.
Spectrin extracts were also subjected to limited tryptic digestion and the tryptic fragments obtained were analyzed by two-dimensional (isoelectric focusing/SDS-PAGE) electrophoresis. In one Black family, the infant (A.B.) exhibited a striking reduction in the normal $80-\mathrm{kD}$ spectrin alpha chain fragment accompanied by the appearance of 65-, 50-, and 21-kD fragments. Digested spectrin from this infant's father, who was not elliptocytic, exhibited a less striking reduction in the $80-\mathrm{kD}$ fragment. Two of the abnormal fragments $(50 \mathrm{kD}, 21 \mathrm{kD})$ noted in infant A.B. were also found in the father's digest. Digested spectrin from the ellip- 


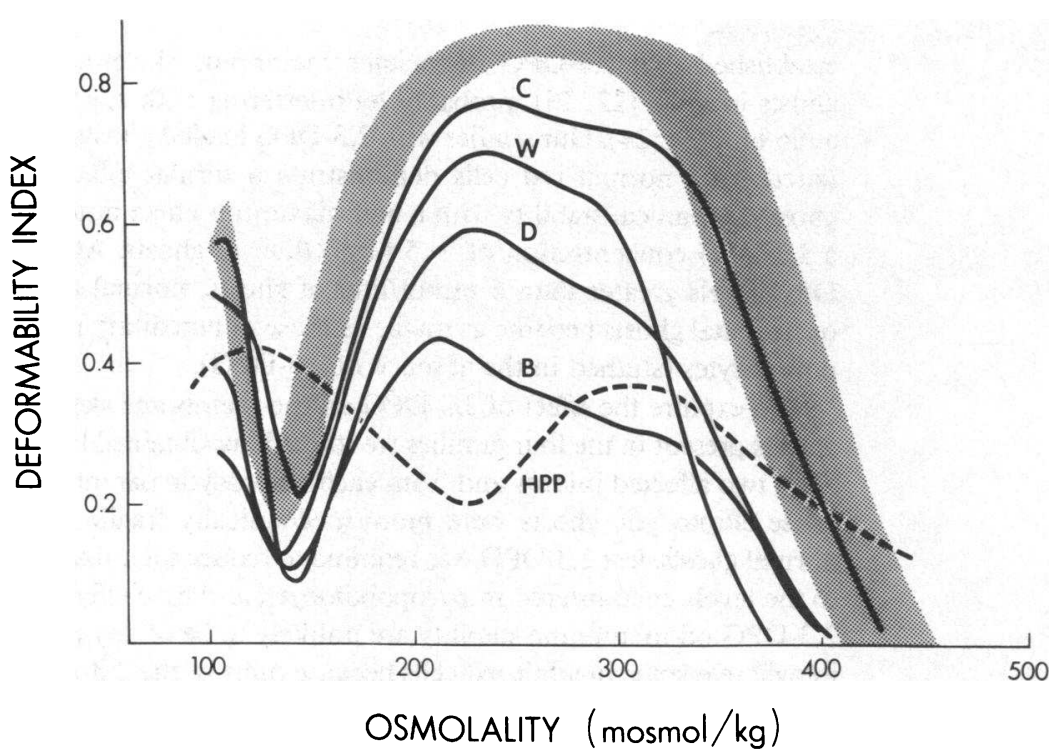

Figure 3. Red cell osmotic gradient ektacytometry in four infants (J.C., age 9 mo; S.W., age 7 wk; B.D., age 5 wk; A.B., age $16 \mathrm{wk}$ ) with neonatal poikilocytosis and transient hemolytic anemia. Results are identified by last name initial. Normal values (shaded area) and representative results in a patient (age $4 \mathrm{yr}$ ) with classic HPP are also indicated. tocytic mother of infant A.B. contained less than the normal amount of the $80-\mathrm{kD}$ fragment along with a reciprocal increase in a $65-\mathrm{kD}$ fragment. In the second Black family (family $\mathrm{D}$ ), the spectrin tryptic digestion pattern in the elliptocytic father and in both elliptocytic children (B.D. and P.D.) showed an increase in the amount of a $65-\mathrm{kD}$ fragment and a concomitant reduction in the amount of the normal $80-\mathrm{kD}$ fragment. The mother's pattern was normal. In the two Caucasian infants (S.W. and J.C.) and their parents, the pattern of tryptic fragments was normal.

\section{Effect of 2,3-DPG on membrane mechanical stability}

To evaluate the effect of 2,3-DPG on membrane mechanical stability, ghosts were resealed in the presence of varying amounts of 2,3-DPG. The mechanical stability of 2,3-DPG loaded ghosts was then measured using the ektacytometer. As shown in Fig. 4, a reduction in ghost mechanical stability was first noted in normal ghosts (from either adults or newborns) at 2,3-DPG concentrations $>3 \mathrm{mmol} /$ liter of ghosts. A halfmaximal effect was evident at $\sim 5 \mathrm{mmol} /$ liter of ghosts. Sufficient blood was obtained to perform similar experiments in two of the four infants with poikilocytosis. At the time they were studied, the 2,3-DPG concentration in fresh red cells (normal $=4.5 \pm 0.6 \mathrm{mmol} / \mathrm{liter}$ red blood cells $\mathrm{RBC}$ ) was $6.7 \mathrm{mmol} / \mathrm{liter} \mathrm{RBC}$ in infant A.B. (age $7 \mathrm{mo}$ ) and $5.4 \mathrm{mmol} /$ liter RBC in infant B.D. (age $8 \mathrm{mo}$ ). Ghost mechanical stability was considerably less than normal, even in the absence of 2,3-DPG. In the presence of 2,3-DPG, ghost mechanical stability decreased further, reaching the extremely fragile levels characteristic of hereditary pyropoikilocytosis at $\sim 4 \mathrm{mmol} /$ liter of ghosts. Ghosts from the elliptocytic parent of each of the four poikilocytic infants also exhibited diminished mechanical stability in the absence of 2,3-DPG. The addition of 2,3DPG further diminished their mechanical stability and, as was the case with the poikilocytic infants, they became as fragile as hereditary pyropoikilocyte ghosts at 2,3-DPG levels of 3.5-5 mmol/liter of ghosts.

In one family (D), a direct comparison between two individuals with an identical molecular defect in spectrin was possible. In this family, the poikilocytic infant's ghosts (B.D.) reached the level of mechanical fragility characteristic of hereditary pyropoikilocytosis at a 2,3-DPG level of 2.5 $\mathrm{mmol} /$ liter ghosts (Fig. 4), while ghosts from his elliptocytic father (K.D.), studied on two separate occasions, reached the same level at 2,3-DPG levels of $4.5 \mathrm{mmol} /$ liter ghosts (Fig. 4) or $2.6 \mathrm{mmol} /$ liter ghosts (data not shown).

\section{Discussion}

The five infants described in this report each had significant nonimmune hemolytic anemia during the first few months of life. In three, (J.C., B.D., P.D.), anemia and reticulocytosis dis- appeared by 6 mo of age, poikilocytes disappeared or became less prevalent, and elliptocytes became the predominant circulating red cell. The residual erythrocyte abnormality now present in these children is best classified as the mild form of common hereditary elliptocytosis (20). The fourth infant (S.W.), also now has mild common hereditary elliptocytosis but, unlike the first two infants, shows evidence of persistent compensated hemolysis at age $2 \mathrm{yr}$. The last infant (A.B.), who at age $2 \mathrm{yr}$ and $10 \mathrm{mo}$ also continues to exhibit compensated hemolysis, appears to represent an example of mild or variant hereditary pyropoikilocytosis, since his red cells remain bizarrely poikilocytic and exhibit striking thermal fragility that has not improved as he has matured. The abnormalities in red cell rheology and in spectrin biochemistry discovered in both parents suggest that this infant is a compound heterozygote for two different membrane abnormalities, an inheritance pattern reported previously in hereditary pyropoikilocytosis (10). In contrast, in the other three families, one parent had elliptocytosis accompanied by a reduction in ghost mechanical fragility while the other parent was normal, suggesting that the cytoskeletal abnormalities present in the infant were inherited solely from the elliptocytic parent.

Our attempts to define the erythrocyte membrane protein abnormalities present in these infants highlighted the differences between them. A spectrin alpha subunit defect $\left(\mathrm{Sp} \alpha^{1 / 65}\right)$ was detected in family $\mathrm{D}$, and in family $\mathrm{W}$ a previously undescribed electrophoretic variant of the spectrin alpha subunit was found. In family $\mathrm{B}$, two different spectrin mutations ( $\left.\mathrm{Sp} \alpha^{1 / 65}, \mathrm{Sp} \alpha^{1 / 50}\right)$ were found in the parents. Both mutations appeared to have been inherited by the infant (A.B.), who had hereditary pyropoikilocytosis. In family $\mathrm{C}$, no evidence of a spectrin mutation was discovered. Thus the clinical, rheological, and biochemical evidence all indicated that a different membrane skeletal defect was present in each of the four families.

In searching for a common cause for the transient hemolytic anemia, we considered three possibilities. The first was that unique fetal membrane skeletal proteins were present at birth but were replaced during early infancy by adult counterpart proteins. This possibility seemed unlikely since others have found no evidence that the normal erythrocyte membrane skeleton is structurally different in neonatal red cells than in adult cells (79). Consistent with these observations, we found that ghosts prepared from either normal neonatal or adult erythrocytes had 


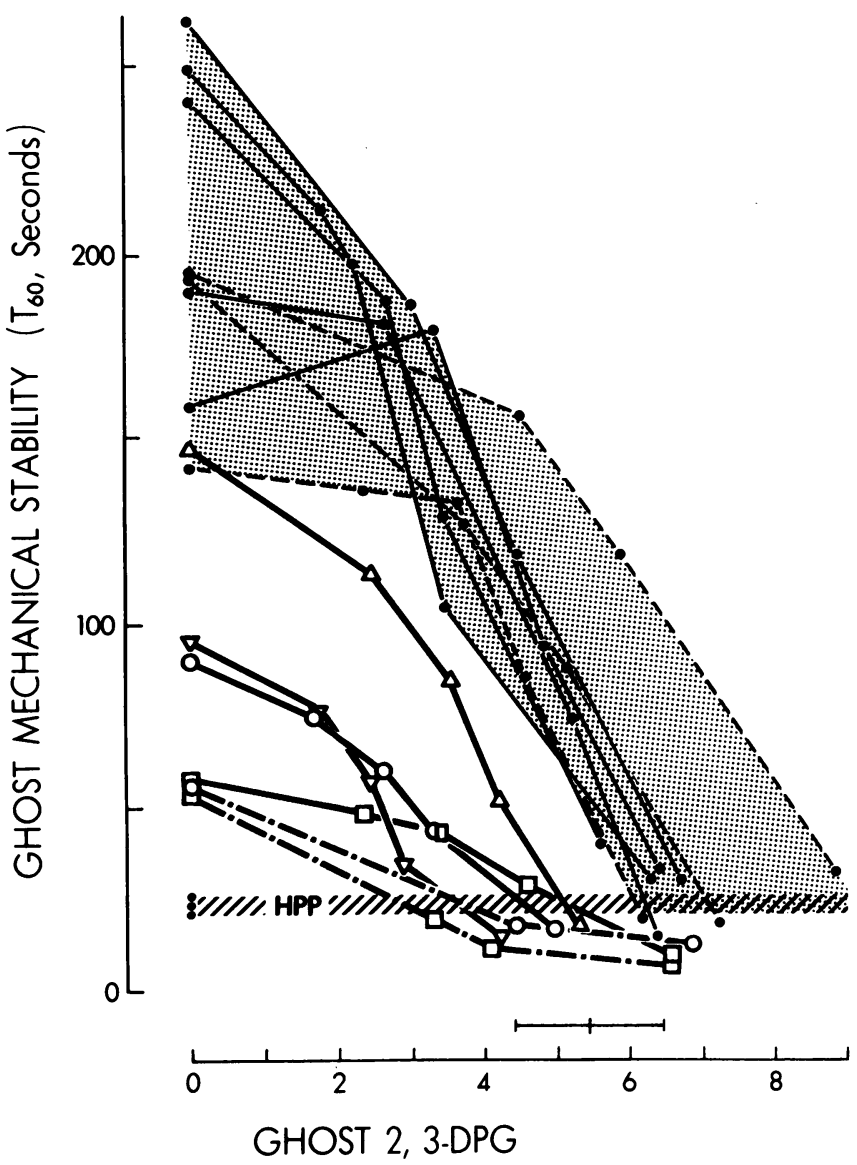

Figure 4. Effect of 2,3-DPG on ghost mechanical stability. Ghosts were loaded with varying amounts of 2,3-DPG in vitro and their mechanical stability then determined in the ektacytometer. Shaded area, range for normal adult $(\bullet-\bullet)$ and neonatal $(\bullet---\bullet)$ red cell ghosts. Results for elliptocytic parents $(\Delta-\Delta=$ mother of J.C., $\nabla-\nabla=$ mother of S.W., $\triangle-O=$ mother of A.B., $\square-\square$ $=$ father of B.D.) and for infants with neonatal poikilocytosis and transient hemolytic anemia ( $\square-\cdot \cdot \cdot-\square=$ B.D., $0-\cdot \cdot \cdot-0=$ A.B.) are also presented. The cross-hatched area labeled HPP indicates the ghost mechanical stability (without added 2,3-DPG) found in five patients (4-29 yr of age) who had hereditary pyropoikilocytosis. The normal 2,3-DPG concentration in neonatal red cells (25), expressed in millimolars per liter. RBC is shown by the horizontal bar (mean \pm SD) just above the abscissa.

equivalent mechanical stability and the same susceptibility to 2,3-DPG induced mechanical fragility. In the anemic infants, there was no discernable relationship between ghost mechanical stability and age. No consistent change in the percent of spectrin dimers was noted in the serial studies carried out in three infants.

We also considered the possibility that the hypofunctional reticuloendothelial system of the neonate (21) might not remove damaged red cells efficiently and allow the accumulation of a population of poikilocytes. However, a prolongation rather than a shortening of red cell survival would be anticipated under these circumstances so that the hemolysis associated with infantile poikilocytosis is unlikely to be explained by altered reticuloendothelial function.

The final possibility we considered was that developmental changes in the concentration of free 2,3-DPG might result in transient neonatal hemolytic anemia. The work of others has established that 2,3-DPG dissociates membrane skeletons or ghosts in vitro $(22,23)$, probably by interfering with spectrinactin binding (24). Our studies with 2,3-DPG loaded ghosts prepared from normal red cells demonstrate a similar effect on ghost mechanical stability with a half maximum effect noted at a 2,3-DPG concentration of $\sim 5 \mathrm{mmol} /$ liter of ghosts. At 2,3DPG levels greater than $6 \mathrm{mmol} /$ liter of ghosts, normal adult or neonatal ghosts become as fragile as those of hereditary pyropoikilocytes (studied in the absence of 2,3-DPG).

To explore the effect of 2,3-DPG on the membrane skeletal defects present in the four families we studied, we obtained blood from two affected infants and from each elliptocytic parent. Because elliptocytic ghosts were more mechanically fragile than normal ghosts, less 2,3-DPG was required to reduce their fragility to the levels encountered in pyropoikilocytosis. These effects of 2,3-DPG on membrane stability are unlikely to be of any physiologic relevance in adult red cells because most of the 2,3-DPG in such cells is bound to deoxyhemoglobin A. However in newborn red blood cells, the predominant hemoglobin is fetal hemoglobin which binds 2,3-DPG only to a very limited extent (25). Therefore, the majority of intracellular 2,3-DPG should be continually available to interact with cytoskeletal membrane proteins. The concentration of 2,3-DPG in neonatal red cells is $5.4 \pm 1.0 \mathrm{mmol} /$ liter of red cells, a level that is maintained throughout the first year of life (26). Expressed per liter of red cell water, which should more accurately reflect the concentration of 2,3-DPG in the vicinity of the membrane, the value would be $\sim 30 \%$ higher, or $\sim 7 \mathrm{mmol} /$ liter cell $\mathrm{H}_{2} \mathrm{O}$. Bunn and his colleagues have calculated for adult red cells, assuming the total 2,3-DPG concentration to be $7.2 \mathrm{mmol} /$ liter cell $\mathrm{H}_{2} \mathrm{O}$, that free 2,3-DPG levels in oxygenated red cells would be $5.9 \mathrm{mmol} / \mathrm{liter}$ cell $\mathrm{H}_{2} \mathrm{O}$ and in deoxygenated red cells $0.53 \mathrm{mmol} /$ liter cell $\mathrm{H}_{2} \mathrm{O}$ (27). In both oxygenated and deoxygenated neonatal red cells, the free 2,3-DPG concentration should be equivalent to that of oxygenated adult cells, since deoxyhemoglobin $\mathrm{F}$ does not bind 2,3-DPG. Clearly, such levels are sufficient to weaken the membrane skeleton. The effect would be particularly striking in the presence of an inherited defect of the membrane skeleton. As hemoglobin $\mathrm{F}$ is replaced by hemoglobin A during the first several months after birth an increasing proportion of 2,3-DPG is bound to hemoglobin $A$ and thus unavailable to interact with the membrane skeleton. Once hemoglobin A levels have risen beyond a certain critical point, the membrane dissociating effect of 2,3DPG should largely vanish and only the underlying inherited protein abnormality responsible for elliptocytosis would remain.

Several questions raised by our observations cannot be fully addressed at this time. First, if the cells that contain HbF are preferentially destroyed, one might expect $\mathrm{HbF}$ levels to fall more precipitously than normal after birth in affected infants. The limited data available (Fig. 1) is inconclusive in this regard and cannot be interpreted since the possibility of compensatory stimulation of $\mathrm{HbF}$ synthesis remains unexplored. Second, in one of our patients (B.D.) and in several described by others (5), the transition from poikilocytic to elliptocytic morphology and the rise toward normal in the temperature at which heat induced morphological abnormalities are seen did not occur until after 12 mo of age, long after hemoglobin $\mathrm{F}$ levels had declined to $<5 \%$. The underlying basis for these events is not clear but, unlike the extent of hemolysis, they are unlikely to be related to changes in hemoglobin F or free 2,3-DPG levels. Third, not all individuals with $\mathrm{HE}$ exhibit poikilocytosis and hemolysis during infancy, despite the fact that all newborns have high levels 
of $\mathrm{HbF}$. The molecular basis of $\mathrm{HE}$ is heterogeneous and, in the majority of instances, not well defined (20). Presumably, the location or severity of the membrane skeletal defect does not always favor the appearance of poikilocytosis and hemolysis in the presence of increased levels of free 2,3-DPG. Lastly, our studies were largely carried out in ghosts. Whether the effects of 2,3-DPG on ghosts will also be seen in intact red cells has recently been questioned by Waugh (28). Our data in infant P.D. shows that red cell mechanical stability improves during the transition from neonatal poikilocytosis to elliptocytosis, consistent with the hypothesized effect of free 2,3-DPG. However, a direct evaluation of the effect of 2,3-DPG on the mechanical stability of red cells remains to be performed.

Our studies confirm that physiologic levels of 2,3-DPG can produce striking mechanical fragility in red cell ghosts obtained either from adults with elliptocytosis or from their infants with transient poikilocytosis. The abatement of hemolysis in these infants coincides with the developmental decline in hemoglobin $F$ levels. It is reasonable to expect that 2,3-DPG would exert a similar dissociating effect upon a variety of other skeletal protein defects, explaining the heterogeneous nature of the elliptocytic defects susceptible to transient neonatal hemolysis. In fact, the striking degree of hemolysis in early infancy with modest improvement after $6 \mathrm{mo}$ of age observed in severe spherocytosis associated with spectrin deficiency (29) suggests that other, nonelliptocytic, membrane skeletal disorders may also be influenced by 2,3-DPG. Finally, it is conceivable that the membrane dissociating effects of free 2,3-DPG may also contribute to the long recognized but poorly understood shortened lifespan of normal fetal and neonatal red cells (30). Such speculations are the stimulus for further investigations now under way in our laboratories.

\section{Acknowledgments}

We are grateful for the expert secretarial assistance of Cathy Falletta and Jane Lee.

This work was supported by grants from the National Institutes of Health (AM-26263, HD-06633, and AM-32094).

\section{References}

1. Austin, R. F., and J. F. Desforges. 1969. Hereditary elliptocytosis: An unusual presentation of hemolysis in the newborn associated with transient morphologic abnormalities. Pediatrics. 44:196-200.

2. Carpentieri, U., L. P. Gustavson, and M. E. Haggard. 1977. Pyknocytosis in a neonate: An unusual presentation of hereditary elliptocytosis. Clin. Pediat. 16:76-78.

3. Zarkowsky, H. S. 1979. Heat-induced erythrocyte fragmentation in neonatal elliptocytosis. Br. J. Haematol. 41:515-518.

4. Macdougall, L. G., G. Moddley, and M. Quirk. 1982. The pyropoikilocytosis-elliptocytosis syndrome in a black South African infant. Clinical and hematological features. Am. J. Ped. Hematol./Oncol. 4:344349.

5. Prchal, J. T., R. P. Castleberry, R. T. Parmley, W. M. Crist, and A. Malluh. 1982. Hereditary pyropoikilocytosis and elliptocytosis: Clinical, laboratory, and ultrastructural features in infants and children. $\mathrm{Pe}$ diatr. Res. 16:484-489.

6. Matovcik, L. M., and W. C. Mentzer. 1985. The membrane of the human neonatal red cell. Clin. Haematol. 14:203-221.

7. Hajjar, K. A. 1985. Structural and functional analysis of spectrin from neonatal erythrocytes. Biochim. Biophys. Acta. 827:460-465.

8. Lawler, J., S.-C. Liu, J. Palek, and J. Prchal. 1984. A molecular defect of spectrin in a subset of patients with hereditary elliptocytosis.
Alterations in the alpha-subunit domain involved in spectrin self-association. J. Clin. Invest. 73:1688-1695.

9. Palek, J., and S. E. Lux. 1983. Red cell membrane skeletal defects in hereditary and acquired hemolytic anemias. Semin. Hematol. 20:189224.

10. Mentzer, W. C., T. Turetsky, N. Mohandas, S. Schrier, C.-S. C. $\mathrm{Wu}$, and $\mathrm{H}$. Koenig. 1984. Identification of the hereditary pyropoikilocytosis carrier state. Blood. 63:1439-1446.

11. Clark, M. R., N. Mohandas, and S. B. Shohet. 1983. Osmotic gradient ektacytometry. Comprehensive characterization of red cell volume and surface maintenance. Blood. 61:889-910.

12. Mohandas, N., M. R. Clark, B. P. Health, M. Rossi, L. C. Wolfe, S. E. Lux, and S. B. Shohet. 1982. A technique to detect reduced mechanical stability of red cell membranes. Relevance to elliptocytic disorders. Blood. 59:768-774.

13. Dodge, J. T., C. Mitchell, and D. J. Hanahan. 1963. The preparation and chemical characteristics of hemoglobin-free ghosts of human erythrocytes. Arch. Biochem. Biophys. 100:119-130.

14. Laemmli, U. K. 1970. Cleavage of structural proteins during the assembly of the head of bacteriophage T4. Nature (Lond.). 227:680-685.

15. Liu, S. C., and J. Palek. 1980. Spectrin tetramer-dimer equilibrium and the stability of erythrocyte membrane skeletons. Nature (Lond.). 285:586-588.

16. Knowles, W., and M. L. Bologna. 1983. Isolation of chemical domains of human erythrocyte spectrin. Methods Enzymol. 96:305-313.

17. Speicher, D. W., J. S. Morrow, W. J. Knowles, and V. T. Marchesi. 1982. A structural model of human erythrocyte spectrin. J. Biol. Chem. 257:9093-9101.

18. Keitt, A. S. 1971. Reduced nicotinamide adenine dinucleotidelinked analysis of 2,3-diphosphoglyceric acid. Spectrophotometric and fluorometric procedures. J. Lab. Clin. Med. 77:470-475.

19. Lane, P. A., R. L. Shew, T. A. larocci, N. Mohandas, T. Hays, and W. C. Mentzer. 1987. A unique alpha-spectrin mutant in a kindred with common hereditary elliptocytosis. J. Clin. Invest. 79:989-996.

20. Palek, J. 1985. Hereditary elliptocytosis and related disorders. Clin. Haematol. 14:45-88.

21. Holroyde, C. P., F. A. Oski, and F. H. Gardner. 1969. The "pocked" erythrocyte. Red-cell surface alterations in reticuloendothelial immaturity of the neonate. N. Engl. J. Med. 281:516-520.

22. Sheetz, M. P., and J. Casaly. 1980. 2,3-Diphosphoglycerate and ATP dissociate erythrocyte membrane skeletons. J. Biol. Chem. 200: 9955-9960.

23. Chasis, J. A., and N. Mohandas. 1986. Erythrocyte membrane deformability and stability. Two distinct membrane properties that are independently regulated by skeletal protein associations. J. Cell Biol. 103:343-350.

24. Wolfe, L. C., S. E. Lux, and V. Ohanian. 1981. Spectrin-acting binding in vitro: Effect of protein 4.1 and polyphosphates. J. Supramol. Struct. 5(Suppl.):123.

25. Bunn, H. F., and R. W. Briehl. 1970. The interaction of 2,3diphosphoglycerate with various human hemoglobins. J. Clin. Invest. 49:1088-1095.

26. Oski, F. A., and M. Delivoria-Papadopoulos. 1970. The red cell, 2,3-diphosphoglycerate, and tissue oxygen release. J. Pediatr. 77:941956.

27. Bunn, H. F., B. J. Ransil, and A. Chao. 1971. The interaction between erythrocyte organic phosphates, magnesium ion, and hemoglobin. J. Biol. Chem. 246:5273-5279.

28. Waugh, R. E. 1986. Effects of 2,3-Diphosphoglycerate on the mechanical properties of erythrocyte membrane. Blood. 68:231-238.

29. Agre, P., E. P. Orringer, and V. Bennett. 1982. Deficient red-cell spectrin in severe, recessively inherited spherocytosis. N. Engl. J. Med. 306:1155-1161.

30. Pearson, H. A. 1967. Life-span of the fetal red blood cell. $J$. Pediatr. 70:166-171.

31. Lubin, B. H. 1981. Reference values in infancy and childhood. In Hematology of Infancy and Childhood. D. G. Nathan and F. A. Oski, editors. Second ed. W. B. Saunders Co., Philadelphia. 1552-1574. 